\title{
Finding Size Factor and Value Factor in Indonesia Stock Exchange
}

\author{
Yudhistirangga $^{1}$, Hermanto Siregar $^{2} \&$ Trias Andati $^{1}$ \\ ${ }^{1}$ School of Business, Bogor Agricultural University, Bogor, West Java, Indonesia \\ ${ }^{2}$ Department of Economics, Bogor Agricultural University, Bogor, West Java, Indonesia \\ Correspondence: Yudhistirangga, School of Business, Bogor Agricultural University, Jl. Raya Padjajaran, Bogor, \\ West Java, Indonesia. Tel: 62-812-9339-7903. E-mail: yudhistirangga.jogja@gmail.com
}

Received: April 16, 2018 Accepted: May 22, $2018 \quad$ Online Published: June 22, 2018

doi:10.5539/ass.v14n7p63 URL: https://doi.org/10.5539/ass.v14n7p63

\begin{abstract}
This study conducted by gathering data from Indonesia Stock Exchange (IDX) with 2 specifics model, Capital Market Pricing Model (CAPM) and Fama French 3 Factors Model (FF3FM). These model was estimated by classify 557 stocks in Jakarta Composite Index (JCI) to 6 classes: S/L class is class with small size and low Book to Equity (BE) to Market Equity (ME), S/M class is class with small size and medium in BE/ME, $\mathrm{S} / \mathrm{H}$ class is class with small size and high in $\mathrm{BE} / \mathrm{ME}$, otherwise $\mathrm{B} / \mathrm{L}$ class is class with big size and low in $\mathrm{BE} / \mathrm{ME}, \mathrm{B} / \mathrm{M}$ class is class with big size and medium in $\mathrm{BE} / \mathrm{ME}, \mathrm{B} / \mathrm{H}$ class is class with big size and high in $\mathrm{BE} / \mathrm{ME}$. With $\mathrm{F}$ test, $t$ test and classic assumption test, best class and best model were $\mathrm{B} / \mathrm{L}$ class and FF3FM. The result was confirmed size factor and value factor in Indonesia Stock Exchange (IDX). Size factor are confirmed in 3 classes $(\mathrm{S} / \mathrm{M}, \mathrm{S} / \mathrm{H}$ and $\mathrm{B} / \mathrm{L})$, and value factor are confirmed in 4 classes $(\mathrm{S} / \mathrm{M}, \mathrm{S} / \mathrm{H}, \mathrm{B} / \mathrm{L}$ and $\mathrm{B} / \mathrm{H})$. Therefore, classes with size and value factor are $\mathrm{S} / \mathrm{M}, \mathrm{S} / \mathrm{H}$ and $\mathrm{B} / \mathrm{L}$. With $\mathrm{BE} / \mathrm{ME}$ is $1 / \mathrm{PBV}$ and $\mathrm{PBV}$ indicating the stock price relative to its book value, so in Indonesia Stock Exchange the size factor and value factor confirmed in market with small market capitalization with low to medium in stock price relative to its book value and market with big market capitalization with high stock price relative to its book value.
\end{abstract}

Keywords: size factor, value factor, CAPM, FF3FM

\section{Introduction}

After risk and return concept was developed by Markowitz (1952), the era of modern portfolio had just been started. Later, Sharpe (1964), Lintner (1965) and Mossin (1966) developing first theory by Markowitz, known as CAPM model, years after perfected by Jensen (1967) that introduced Jensen's Alpha. Research from Al-Afeef (2017) proved that CAPM could be applied in US market to predict return from 2009-2016 where $20 \%$ of expected return change was caused by beta and other $80 \%$ from other factors. Zeeshan (2016) proved CAPM in Karachi Stock Exchange and Singh, Jain, and Yadav (2016) proved CAPM in Indian Stock Market. Moreover, Poornima and Swathiga (2017) told that with CAPM model, he found that automotive industry has positive return with lower risk compare to IT based industry that has negative return with higher risk.

In fact, based on Lam (2005), said that 73.5\% CFO in United States using CAPM to modeling risk and return, but CAPM left some misunderstanding and misleading towards some special cases. Fama and French (2004) was found some weakness in CAPM such as : 1) CAPM failed to explain some high and low beta cases, 2) CAPM was simple model that just explain risk and return, 3) CAPM was left huge error, proved by high Jensen's alpha value in some special cases. Tanjung, Siregar, Sembel, \& Nurmalina (2014) said that the Jakarta Composite Index (JCI) tend to move down after merger activity that affecting the JCI return and maybe lead to misfit in CAPM.

Later, Fama and French (1993) was developing the CAPM. This model has 3 factors compared to CAPM (just 1 factor), and known as Fama French 3 Factors Model (FF3FM). In this model, instead of portfolio return just explained by single market risk premium, the others 2 factors added to model, size factor and value factor. Size factor is stock market capitalization and value factor is defined by Book to Equity (BE) divided by Market to Equity (ME). This model has been proved by Al-zubi and Salameh (2009), Blanco (2012), Dah, et.al (2015), Kilsgård and Wittorf (2010) and Aldaarmi (2015). Their statements were lead to single conclusion, FF3FM is better than CAPM.

However, Eraslan (2013) said that size factor doesn't exist in stocks that has big market capitalization but just 
exist in medium and low market capitalization. The value factor just appeared in stocks with high Book to Market Ratio. Rossi (2012) found that size factor and beta has strong power of explanation to the model, but no confirmation of value factor.

This study has aim to prove the size factor and value factor in Indonesia Stock Exchange by comparing CAPM and FF3FM. This study will help the investor gather more information to value stocks, give company to strengthen their growth and give a brief explanation to regulator in order to bring a good investment regulations.

\section{Method}

2.1 Capital Asset Pricing Model (CAPM), Fama French 3 Factors Model (FF3FM) dan Dual Beta dalam Fama French 3 Factors Model (FF3FM)

CAPM is linear model of risk and return, statistically wrote as : (Fama and French, 2004; Lam, 2005)

$$
R_{i t}-R_{f t}=\alpha+\beta\left(R_{m t}-R_{f t}\right)+\varepsilon_{i t}
$$

Otherwise, FF3FM is linear model developed by Fama and French (1993) after perfected the CAPM model. Lam (2005) without doubt said that FF3FM was better than CAPM. FF3FM model is linear CAPM with size factor (SMB) and value factor (HML) (Fama dan French, 1993, 2004; Lam, 2005).

$$
R_{i t}-R_{f t}=\alpha+\beta_{i m}\left(R_{m t}-R_{f t}\right)+\beta_{i s}(S M B)+\beta_{i h} H M L+\varepsilon_{i t}
$$

where,

$$
\begin{aligned}
\mathrm{R}_{\mathrm{it}} & : \text { Return of investment in instrument } i \text { on } t \text {-time } \\
\mathrm{R}_{\mathrm{ft}} & : \text { Return of risk free rate in } t \text {-time } \\
\alpha & : \text { Jensen's Alpha, CAPM model intercept } \\
\beta & : \text { sensitivity rate of investment instrument toward risk premium } \\
\mathrm{R}_{\mathrm{mt}}-\mathrm{R}_{\mathrm{ft}} & : \text { risk premium } \\
\mathrm{SMB} & : \text { size factor } \\
\mathrm{HML} & : \text { value factor } \\
\mathrm{R}_{\mathrm{mt}} & : \text { market return in } t \text {-time } \\
\varepsilon_{\mathrm{it}} & : \text { error model }
\end{aligned}
$$

These 2 model will be tested on 6 different class formed from 557 stocks in IDX, named by class S/L, S/M, S/H, $\mathrm{B} / \mathrm{L}, \mathrm{B} / \mathrm{M}$ and $\mathrm{B} / \mathrm{H}$. S/L class is class with small size and low Book to Equity (BE) to Market Equity (ME), S/M class is class with small size and medium in $B E / M E, \mathrm{~S} / \mathrm{H}$ class is class with small size and high in $B E / M E$, otherwise $\mathrm{B} / \mathrm{L}$ class is class with big size and low in $B E / M E, \mathrm{~B} / \mathrm{M}$ class is class with big size and medium in $B E / M E, \mathrm{~B} / \mathrm{H}$ class is class with big size and high in $B E / M E$. CAPM and FF3FM will be tested on 6 different classes to prove size factor and value factor with CAPM act like control model, with hypotheses are follows :

H1: There is no size factor in 6 different class in IDX

$\mathrm{H} 2$ : There is no value factor in 6 different class in IDX

\subsection{Gathering of Data}

The stocks data gathered from Bloomberg and Indonesia Stock Exchange from June 2011 to June 2017 (72 months).

\subsection{Portfolio Construction}

\subsubsection{Stock Selection and Finding 6 Different Classes}

Stocks are collected from IDX and must listed (not delisted) from June 2011 to June 2017 proved by the existing of Price to Book Value (PBV) and Market Capitalization, then 6 different classes formed by classify 557 different stocks to $2 \times 3$ matrix by 2 size categories (small and big) and 3 value categories (low, medium and high), there after 6 different classes named by $\mathrm{S} / \mathrm{L}$ class is class with small size and low Book to Equity (BE) to Market Equity $(M E), \mathrm{S} / \mathrm{M}$ class is class with small size and medium in $B E / M E, \mathrm{~S} / \mathrm{H}$ class is class with small size and high in $B E / M E$, otherwise $\mathrm{B} / \mathrm{L}$ class is class with big size and low in $B E / M E, \mathrm{~B} / \mathrm{M}$ class is class with big size and medium in $B E / M E$, $\mathrm{B} / \mathrm{H}$ class is class with big size and high in $B E / M E$ will be formed. The size factor formed by ascending size data by $50 \%$ percentile to small and big category, then value factor formed by ascending value data by $30 \%$ and $70 \%$ percentile to low, medium and high category (Fama and French, 1993; Kilsgård and 
Wittorf, 2010).

Jakarta Interbank Offering Rate (JIBOR) will be used as risk free according to Zaremba and Konieczka (2015). JIBOR is bank's rate for lending or borrowing in Indonesia. In this study, 1 Month JIBOR used in monthly basis by interpolated yearly basis data gathered from Central Bank of Indonesia (BI).

\subsubsection{Constructing and Testing CAPM and FF3FM}

\subsubsection{Classic Assumption Test}

The regression approach for this study is ordinary least square (OLS), and has to follow the individual $t$ test and $\mathrm{F}$ test. The error model must be free from collinearity, has independence of error, normal assumption of error and no heteroskedasticity (Gujarati, 2004).

\subsubsection{Choosing the Best Class and the Best Model}

In this section, each class will be modeled by CAPM and FF3FM, comparing with $\mathrm{R}^{2}$, and the best class will be choose. After the best class has been choose, CAPM and FF3FM are compaing by paired $t$ test, in accordance to show whether yfits of CAPM is statistically different from FF3FM.

\subsubsection{Determined the Size Factor dan Value Factor}

From the 6 different classes, the size factor and value factor will be determined by looking the significant of the coefficient of regression in $1 \%, 5 \%$ and $10 \%$ of error.

\section{Results}

According to data gathered from IDX, 290 stocks were selected from 557 stocks and 6 different classes, S/L class is class with small size and low Book to Equity (BE) to Market Equity (ME), S/M class is class with small size and medium in $B E / M E, \mathrm{~S} / \mathrm{H}$ class is class with small size and high in $B E / M E$, otherwise $\mathrm{B} / \mathrm{L}$ class is class with big size and low in $B E / M E, \mathrm{~B} / \mathrm{M}$ class is class with big size and medium in $B E / M E, \mathrm{~B} / \mathrm{H}$ class is class with big size and high in $B E / M E$ were formed.

Table 1. Number of Stocks in Each Class

\begin{tabular}{|c|c|c|c|c|c|c|c|}
\hline Year & $\mathrm{S} / \mathrm{L}$ & $\mathrm{S} / \mathrm{M}$ & $\mathrm{S} / \mathrm{H}$ & $\mathrm{B} / \mathrm{L}$ & $\mathrm{B} / \mathrm{M}$ & $\mathrm{B} / \mathrm{H}$ & Total \\
\hline 2011 & 24 & 52 & 69 & 63 & 64 & 18 & 290 \\
\hline 2012 & 17 & 55 & 73 & 70 & 61 & 14 & 290 \\
\hline 2013 & 13 & 56 & 76 & 74 & 60 & 11 & 290 \\
\hline 2014 & 15 & 54 & 76 & 72 & 62 & 11 & 290 \\
\hline 2015 & 13 & 58 & 74 & 74 & 58 & 13 & 290 \\
\hline 2016 & 17 & 56 & 72 & 70 & 60 & 15 & 290 \\
\hline Mean & 16.50 & 55.17 & 73.33 & 70.50 & 60.83 & 13.67 & \\
\hline St. Dev. & 4.09 & 2.04 & 2.66 & 4.09 & 2.04 & 2.66 & \\
\hline Max & 24.00 & 58.00 & 76.00 & 74.00 & 64.00 & 18.00 & \\
\hline Min & 13.00 & 52.00 & 69.00 & 63.00 & 58.00 & 11.00 & \\
\hline
\end{tabular}

The $\mathrm{S} / \mathrm{H}$ Class is class with highest member of stocks, followed by $\mathrm{B} / \mathrm{L}, \mathrm{B} / \mathrm{M}, \mathrm{S} / \mathrm{M}, \mathrm{S} / \mathrm{L}$ and $\mathrm{B} / \mathrm{H}$. From table 1 , $\mathrm{S} / \mathrm{M}$ and $\mathrm{B} / \mathrm{M}$ class members relatively stable, but $\mathrm{S} / \mathrm{L}$ and $\mathrm{B} / \mathrm{L}$ show high volatility in their member (showed by its standard deviation). From table 1, CAPM and FF3FM applied to 6 classes and the results are follows.

Table 2. CAPM

\begin{tabular}{|c|c|c|c|c|c|c|c|c|}
\hline & $\alpha$ & $\underset{(\mathrm{Rm}-\mathrm{Rf})}{\beta \text { im }}$ & $\mathrm{R}^{2}$ & $\mathrm{R}^{2}(\mathrm{adj})$ & $\begin{array}{c}\text { Normality } \\
\text { Test }\end{array}$ & $\begin{array}{c}\text { Auto- } \\
\text { Correlation } \\
\text { Check }\end{array}$ & $\begin{array}{c}\text { Multi- } \\
\text { Collinearity } \\
\text { Check }\end{array}$ & $\begin{array}{c}\text { Homos- } \\
\text { Cedasticity } \\
\text { Check }\end{array}$ \\
\hline $\mathrm{S} / \mathrm{L}$ & -0.123 & $0.788^{*}$ & $13.34 \%$ & $12.11 \%$ & $x$ & $\sqrt{ }$ & $\sqrt{ }$ & $\sqrt{ }$ \\
\hline $\mathrm{S} / \mathrm{M}$ & -0.107 & $0.865^{*}$ & $43.26 \%$ & $42.44 \%$ & $\times$ & $\sqrt{ }$ & $\sqrt{ }$ & $\sqrt{ }$ \\
\hline $\mathrm{S} / \mathrm{H}$ & -0.462 & $0.984^{*}$ & $49.87 \%$ & $49.16 \%$ & $\sqrt{ }$ & $\sqrt{ }$ & $\sqrt{ }$ & $\sqrt{ }$ \\
\hline $\mathrm{B} / \mathrm{L}$ & $0.804 *$ & $0.950 *$ & $91.29 \%$ & $91.17 \%$ & $\sqrt{ }$ & $\sqrt{ }$ & $\sqrt{ }$ & $\sqrt{ }$ \\
\hline $\mathrm{B} / \mathrm{M}$ & -0.059 & $1.241 *$ & $85.29 \%$ & $85.08 \%$ & $\times$ & $\times$ & $\sqrt{ }$ & $\sqrt{ }$ \\
\hline $\mathrm{B} / \mathrm{H}$ & -0.254 & $1.507^{*}$ & $50.77 \%$ & $50.07 \%$ & $\sqrt{ }$ & $x$ & $\sqrt{ }$ & $\sqrt{ }$ \\
\hline
\end{tabular}


Table 3. FF3FM

\begin{tabular}{|c|c|c|c|c|c|c|c|c|c|c|}
\hline & $\alpha$ & $\begin{array}{c}\beta \_ \text {im } \\
(\mathrm{Rm}-\mathrm{Rf})\end{array}$ & $\begin{array}{l}\beta \_ \text {is } \\
\text { SMB }\end{array}$ & $\begin{array}{l}\beta \_ \text {ih } \\
\text { HML }\end{array}$ & $\mathrm{R}^{2}$ & $\mathrm{R}^{2}$ (adj) & $\begin{array}{c}\text { Normality } \\
\text { Test }\end{array}$ & $\begin{array}{c}\text { Auto- } \\
\text { Correlation } \\
\text { Check }\end{array}$ & $\begin{array}{c}\text { Multi- } \\
\text { Collinearity } \\
\text { Check }\end{array}$ & $\begin{array}{c}\text { Homos- } \\
\text { Cedasticity } \\
\text { Check }\end{array}$ \\
\hline $\mathrm{S} / \mathrm{L}$ & -0.011 & $1.396^{*}$ & $1.180^{*}$ & $-0.507^{*}$ & $73.02 \%$ & $71.83 \%$ & $\sqrt{ }$ & $\times$ & $\sqrt{ }$ & $\sqrt{ }$ \\
\hline $\mathrm{S} / \mathrm{M}$ & $0.621 * *$ & $0.987^{*}$ & $0.908^{*}$ & $0.530 *$ & $78.80 \%$ & $77.87 \%$ & $\sqrt{ }$ & $\sqrt{ }$ & $\sqrt{ }$ & $\sqrt{ }$ \\
\hline $\mathrm{S} / \mathrm{H}$ & $0.356 * * *$ & $1.054 *$ & $0.903^{*}$ & $0.660 *$ & $92.39 \%$ & $92.05 \%$ & $\sqrt{ }$ & $\sqrt{ }$ & $\sqrt{ }$ & $\sqrt{ }$ \\
\hline $\mathrm{B} / \mathrm{L}$ & $0.676^{*}$ & $0.940 *$ & $-0.140^{*}$ & $-0.104^{*}$ & $93.36 \%$ & $93.07 \%$ & $\sqrt{ }$ & $\sqrt{ }$ & $\sqrt{ }$ & $\sqrt{ }$ \\
\hline $\mathrm{B} / \mathrm{M}$ & -0.020 & $1.216^{*}$ & -0.005 & 0.059 & $85.83 \%$ & $85.20 \%$ & $\times$ & $\sqrt{ }$ & $\sqrt{ }$ & $\sqrt{ }$ \\
\hline $\mathrm{B} / \mathrm{H}$ & 0.309 & $1.281 *$ & 0.137 & $0.729 *$ & $78.44 \%$ & $77.49 \%$ & $\sqrt{ }$ & $\sqrt{ }$ & $\sqrt{ }$ & $\sqrt{ }$ \\
\hline
\end{tabular}

* : Significant level of $1 \%$

** : Significant level of 5\%

$* * *$ : Significant level of $10 \%$

Normality test by Kolmogorov-Smirnov (Siegel 1956), Autocorrelation test by Ljung-Box Q Stats (Ljung \& Box, 1978), Multicollinearity test by VIF Value (for FF3FM) with value 1.154, 1.685 and 1.539 (Gujarati, 2004) and Homoscedasticity test by Rank-Spearman Correlation Test (Gujarati, 2004). Shadowed cells indicated violation against the test.

From Table 2 and Table 3, FF3FM bring better $\mathrm{R}^{2}$ value especially in $\mathrm{S} / \mathrm{L}, \mathrm{S} / \mathrm{M}, \mathrm{S} / \mathrm{H}$ and $\mathrm{B} / \mathrm{H}$. In $\mathrm{S} / \mathrm{L}$ class $\mathrm{R}^{2}$ rise from $12.11 \%$ with CAPM to $71.83 \%$ with FF3FM, then in S/M class $\mathrm{R}^{2}$ rise from $42.44 \%$ with CAPM to $77.87 \%$ with $\mathrm{FF} 3 \mathrm{FM}$, then in $\mathrm{S} / \mathrm{H}$ class $\mathrm{R}^{2}$ rise from $49.16 \%$ with $\mathrm{CAPM}$ to $92.05 \%$ with $\mathrm{FF} 3 \mathrm{FM}$ and then in $\mathrm{B} / \mathrm{H}$ class $\mathrm{R}^{2}$ rise from $50.07 \%$ with CAPM to $77.49 \%$ with FF3FM. From this finding, show that with $\mathrm{R}^{2}$ calculation, FF3FM alone can bring better the $\mathrm{R}^{2}$ value than CAPM. So, in Indonesia Stock Exchange, the return of individual stock are not only explain by market risk premium (RMF) only, but also with size factor and value factor.

\section{Discussion}

\subsection{Best Class and Best Approaching Model}

After $\mathrm{t}$ test, $\mathrm{F}$ test and classic assumption test conducted in 6 different classes with 2 deffirent models (CAPM and $\mathrm{FF} 3 \mathrm{FM}$ ), $\mathrm{B} / \mathrm{L}$ class is the best class with $\mathrm{R}^{2}$ in $91.17 \%$ and $93.07 \%$, respectively. The result from these 2 models, show that FF3FM is better than CAPM. The CAPM just confirming 1 class (B/L), but FF3FM, confirming 3 classes ( $\mathrm{S} / \mathrm{M}, \mathrm{S} / \mathrm{H}$ and $\mathrm{B} / \mathrm{L}$ ).

Table 4. Comparison between CAPM and FF3FM

\begin{tabular}{ccc}
\hline & CAPM & FF3FM \\
\hline Number of Class & 1 & 3 \\
Highest $\mathrm{R}^{2}$ & $91.17 \%$ & $93.07 \%$ \\
Name of Class & $\mathrm{B} / \mathrm{L}$ & $\mathrm{B} / \mathrm{L}$ \\
\hline
\end{tabular}

From B/L class, the best class among 6 classes, CAPM and FF3FM must be tested to show, are there any significant difference from $y$ fits modeled by CAPM dan FF3FM with paired t-test. Table below showed that $y$ fits modeled by CAPM is significantly different in 5\% of error from FF3FM, so the best model is FF3FM.

Table 5. Paired $t$ test on CAPM and FF3FM

\begin{tabular}{ccc}
\hline Paired t-test & \multicolumn{2}{c}{ CAPM vs. FF3FM } \\
\hline $95 \%$ Confidence Interval & -0.1305 & 0.1305 \\
$\mathrm{~N}$ & 72 & \\
Mean Difference & 0.0000 & \\
t-value & 0.00 & \\
p-value & 1 \\
\hline
\end{tabular}




\subsection{Size Factor and Value Factor}

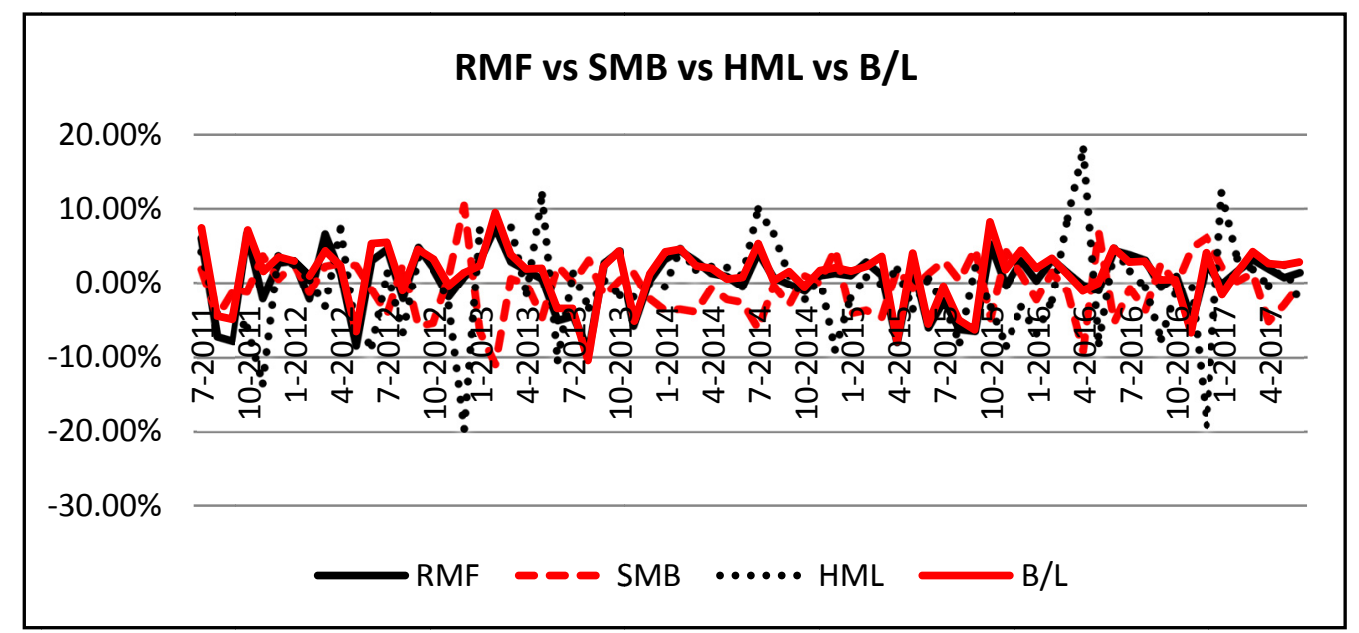

Figure 1. Comparison between RMF, SMB, HML in B/L Class

Monthly return of RMF, SMB and HML in B/L class indicating that RMF and SMB correlation is relatively strong (36.5\% negative correlation), but correlation between RMF and HML is not significant in 5\% of error. However correlation between SMB and HML are 59.2\% negative correlation, means if the return of SMB is going up, $59.2 \%$ chance of return in HML will be going down. So, in $\mathrm{B} / \mathrm{L}$ Class, if some specific stocks return with high market capitalization (B: Big) is going up, then these stocks are relatively expensive in price (L : Low 1/PBV).

Table 6. FF3FM

\begin{tabular}{ccccccccccc}
\hline & $\alpha$ & $\begin{array}{c}\beta_{-} \text {im } \\
\text { (Rm- } \\
\text { Rf) }\end{array}$ & $\begin{array}{c}\beta_{-} \text {is } \\
\text { SMB }\end{array}$ & $\begin{array}{c}\beta_{-} \text {ih } \\
\text { HML }\end{array}$ & $\mathrm{R}^{2}$ & $\mathrm{R}^{2}$ (adj) & $\begin{array}{c}\text { Normality } \\
\text { Test }\end{array}$ & $\begin{array}{c}\text { Auto- } \\
\text { Correlation } \\
\text { Check }\end{array}$ & $\begin{array}{c}\text { Multi- } \\
\text { Collinearity } \\
\text { Check }\end{array}$ & $\begin{array}{c}\text { Homos- } \\
\text { Cedasticity } \\
\text { Check }\end{array}$ \\
\hline S/L & -0.011 & $1.396^{*}$ & $1.180^{*}$ & $-0.507^{*}$ & $73.02 \%$ & $71.83 \%$ & $\sqrt{ }$ & $\times$ & $\sqrt{ }$ & $\sqrt{ }$ \\
S/M & $0.621^{* *}$ & $0.987^{*}$ & $0.908^{*}$ & $0.530^{*}$ & $78.80 \%$ & $77.87 \%$ & $\sqrt{ }$ & $\sqrt{ }$ & $\sqrt{ }$ & $\sqrt{ }$ \\
S/H & $0.356^{* * *}$ & $1.054^{*}$ & $0.903^{*}$ & $0.660^{*}$ & $92.39 \%$ & $92.05 \%$ & $\sqrt{ }$ & $\sqrt{ }$ & $\sqrt{ }$ & $\sqrt{ }$ \\
$\mathrm{B} / \mathrm{L}$ & $0.676^{*}$ & $0.940^{*}$ & $-0.140^{*}$ & $-0.104^{*}$ & $93.36 \%$ & $93.07 \%$ & $\sqrt{ }$ & $\sqrt{ }$ & $\sqrt{ }$ & $\sqrt{ }$ \\
$\mathrm{B} / \mathrm{M}$ & -0.020 & $1.216^{*}$ & -0.005 & 0.059 & $85.83 \%$ & $85.20 \%$ & $\times$ & $\sqrt{ }$ & $\sqrt{ }$ & $\sqrt{ }$ \\
$\mathrm{B} / \mathrm{H}$ & 0.309 & $1.281^{*}$ & 0.137 & $0.729^{*}$ & $78.44 \%$ & $77.49 \%$ & $\sqrt{ }$ & $\sqrt{ }$ & $\sqrt{ }$ & $\sqrt{ }$ \\
\hline
\end{tabular}

* : Significant level of $1 \%$

** : Significant level of 5\%

$* * *$ : Significant level of $10 \%$

The size factor isn't confirmed in B/M and B/H class, and value factor isn't confirmed in B/M class. Size factor only found in $\mathrm{S} / \mathrm{M}, \mathrm{S} / \mathrm{H}$ and $\mathrm{B} / \mathrm{L}$ (3 classes) and value factor found in $\mathrm{S} / \mathrm{M}, \mathrm{S} / \mathrm{H}, \mathrm{B} / \mathrm{L}$ and $\mathrm{B} / \mathrm{H}$ (4 classes), excluding $\mathrm{S} / \mathrm{L}$ and $\mathrm{B} / \mathrm{M}$ classes for violating the classic assumption test. Classes with size and value factor are $\mathrm{S} / \mathrm{M}, \mathrm{S} / \mathrm{H}$ and $\mathrm{B} / \mathrm{L}$. With $\mathrm{BE} / \mathrm{ME}$ is $1 / \mathrm{PBV}$ and $\mathrm{PBV}$ indicating the stock price relative to its book value, so in Indonesia Stock Exchange the size factor and value factor confirmed in market with small market capitalization with low to medium in stock price relative to its book value and market with big market capitalization with high stock price relative to its book value.

\section{Conclusion}

Size factor are confirmed in 3 classes $(\mathrm{S} / \mathrm{M}, \mathrm{S} / \mathrm{H}$ and $\mathrm{B} / \mathrm{L})$, and value factor are confirmed in 4 classes $(\mathrm{S} / \mathrm{M}, \mathrm{S} / \mathrm{H}$, $\mathrm{B} / \mathrm{L}$ and $\mathrm{B} / \mathrm{H}$ ). This result are different from Eraslan (2013) or Rossi (2012) and confirmed significant improvement in $\mathrm{R}^{2}$ value with FF3FM.

Classes with size and value factor are $\mathrm{S} / \mathrm{M}, \mathrm{S} / \mathrm{H}$ and $\mathrm{B} / \mathrm{L}$. With $\mathrm{BE} / \mathrm{ME}$ is $1 / \mathrm{PBV}$ and $\mathrm{PBV}$ indicating the stock price relative to its book value, so in Indonesia Stock Exchange the size factor and value factor confirmed in market with small market capitalization with low to medium in stock price relative to its book value and market 
with big market capitalization with high stock price relative to its book value.

This study also finding that the best class is $\mathrm{B} / \mathrm{L}$ class with $93.07 \%$ in $\mathrm{R}^{2}$ compare to CAPM. If some specific stocks return in $\mathrm{B} / \mathrm{L}$ class with high market capitalization (B: Big) is going up, then these stocks are relatively expensive in price (L: Low 1/PBV).

\section{References}

Al-Afeef, M. A. (2017). Capital Asset Pricing Model, Theory and Practice: Evidence from USA (2009-2016). International Journal of Business and Management, 12(8), 182-192. https://doi.org/10.5539/ijbm.v12n8p182

Al-zubi, K. A., \& Salameh, H. M. (2009). Tests of the Fama and French Three Factor Model in Iran. Iranian Economic Review, 15(1), 4-25.

Aldaarmi, A. A. A. (2015). An Electronic Financial System Adviser for Investors:The Case of Saudi Arabia. Brunel University London.

Blanco, B. (2012). The use of CAPM and Fama and French three factor model: Portfolios Selection. Public and Municipal Finance (hybrid), 1(2), 61-70.

Dah, M., Hoque, M., \& Wang, S. (2015). Constrained Investments and Opportunity Cost - Evidence from Islamic Funds. Managerial Finance, 41(4), 348-367. https://doi.org/10.1108/MF-06-2014-0179

Eraslan, V. (2013). Fama and French Three-Factor Model: Evidence from Istanbul Stock Exchange. Business and Economics Research Journal, 4(2), 11-22. Retrieved from http://search.proquest.com/docview/141604 0105?accountid=13042\%5Cnhttp://oxfordsfx.hosted.exlibrisgroup.com/oxford?url_ver=Z39.88-2004\&rft_v al_fmt=info:ofi/fmt:kev:mtx:journal\&genre=article\&sid=ProQ:ProQ:econlitshell\&atitle=Fama+and+Frenc $\mathrm{h}+$ Three-Factor+Mod

Fama, E. F., \& French, K. R. (1993). Common risk factors in the returns On stocks and bonds. Journal of Financial Economics, 33(1), 3-56.

Fama, E. F., \& French, K. R. (2004). The Capital Asset Pricing Model:Theory and Evidence. Journal of Economic Perspectives, 18(3), 25-46.

Gujarati, D. N. (2004). Basic Econometrics (4th ed.). New York: The McGraw-Hill Companies. https://doi.org/10.2307/2344828

Jensen, M. C. (1967). The Performance of Mutual Funds in the Period 1945-1964. The Journal of Finance, 23(2), 389-416.

Kilsgård, D., \& Wittorf, F. (2010). The Fama and French Three-Factor Model - Evidence from the Swedish Stock Market. Lunds Universitet.

Lam, K. (2005). Is the Fama - French Three Factor Model Better Than the CAPM? Simon Fraser University.

Lintner, J. (1965). The Valuation of Risk Assets and the Selection of Risky Investments in Stock Portfolios and Capital Budgets. The Review of Economics and Statistics, 47(1), 13-37. https://doi.org/10.2307/1924119

Ljung, G. M., \& Box, G. E. P. (1978). On a Measure of Lack of Fit in Time Series Models. Biometrika, 65(2), 297-303. https://doi.org/10.2307/2335207

Markowitz, H. (1952). Portfolio Selection. The Journal of Finance, 7(1), 77-91. https://doi.org/10.1111/j.1540-6261.1952.tb01525.x

Mossin, J. (1966). Equilibrium in a Capital Asset Market. Econometrica, 34(4), 768-783.

Poornima, S., \& Swathiga, P. (2017). A study on relationship between risk and return analysis of selected stocks on NSE using capital asset pricing model. International Journal of Applied Research, 3(7), 375-378.

Rossi, F. (2012). The Three-Factor Model: Evidence from The Italian Stock Market. Research Journal of Finance and Accounting, 3(9), 151-160.

Sharpe, W. F. (1964). Capital asset prices: A theroy of market equilibrium under conditions of risk. The Journal of Finance, 19(3), 425-442. https://doi.org/10.2307/2329297

Siegel, S. (1956). Nonparametric Statistics for The Behavioral Sciences. New York: The McGraw-Hill Companies. https://doi.org/ISBN-10: 0070573573, ISBN-13: 978-0070573574

Singh, S., Jain, P. K., \& Yadav, S. S. (2016). Expected Rates of Equity Returns : Evidence from Indian Stock Market. Journal of Financial Management \& Analysis, 29(1), 48-64. 
Tanjung, H., Siregar, H., Sembel, R., \& Nurmalina, R. (2014). Factors Affecting the Volatility of the Jakarta Composite Index before and after the Merger of Two Stock and Bond Markets in Indonesia. Asian Social Science, 10(22), 91-99. https://doi.org/10.5539/ass.v10n22p91

Zaremba, A., \& Konieczka, P. (2015). Sovereign Wealth Funds in Central and Eastern Europe: Scope and Methods of Financial Penetration. eFinanse Financial Internet Quarterly, 11(1), 11-21. https://doi.org/10.14636/1734-039X

Zeeshan, M. (2016). Capital Asset Price Model Empirical Evidence from Karachi Stock Exchange. Journal of Research in Business and Management, 4(10), 61-67.

\section{Copyrights}

Copyright for this article is retained by the author(s), with first publication rights granted to the journal.

This is an open-access article distributed under the terms and conditions of the Creative Commons Attribution license (http://creativecommons.org/licenses/by/4.0/). 